\title{
Anonymous Revolution?: A Hacker Manifesto Revisited
}

\author{
Garry Potter
}

\begin{abstract}
This is the future, whether one approves or not, and the failure on the part of governments and media alike to understand, and contend with the rapid change now afoot, ought to remind everyone concerned why it is that this movement is necessary in the first place.
\end{abstract}

- Anonymous

\section{Introduction}

We live in a time in which so many things are going or have gone wrong, in which there is so much injustice and where the future seems so fraught with danger that it is difficult not to despair, to fall prey to the deepest cynicism. Because there is so much evidence for pessimism simply to hope becomes intellectually suspect. I begin with this prelude because I wish to seriously argue for something that is as hopeful as it may appear unlikely: that Anonymous is about to become the revolutionary force of our age.

Most of this article however, will not be about Anonymous specifically at all, but rather will be focused upon hackers and vectoralists as written about by MacKenzie Wark (2004) a decade ago. The significance of the insights of A Hacker Manifesto must be clarified and reiterated, and its errors of analysis corrected, before my argument concerning Anonymous can even begin. Wark's thesis places hackers (in his own expansive definition of the term) in a particularly important place, economically and culturally, within the contemporary capitalist moment. My argument stands upon this base to structurally place Anonymous politically in a likewise crucial position within this moment.

Anonymous has been evolving. Its first political action, Operation Chanology, contrary to much of what was said in the media, was initiated principally for the lulz. Anons liked to provoke and then laugh at the impotence of their angry targets. There still exist today many individual Anons and small collectives who believe Anonymous should stay true to their 4Chan and /b/ roots; that is to say, there are those among them who believe Anonymous should be apolitical pranksters and that all this talk about freedom and injustice are pretention. But they are a minority; the vast majority of Anons came to fully take on board the rebel hero role the media bestowed upon them. Today there are many new recruits to the Anonymous banner who know little and care less about 4chan and /b/ and their shared mimetic culture; they have been drawn to Anonymous, at least partly, for political reasons. I will argue that now it is the case for many Anons that they were drawn to Anonymous because of the frustration and lack of control of their individual lives and the power that is potentially manifest in anonymous collectivity. They are not consciously Marxist, or at least very few of them are, but they have come to recognize their own class interests in the collective resistance to power that Anonymous expresses. Now they are international and perhaps someday soon will be able to turn one of their most important memes - We are Legion - into fact.

\section{A Hacker Manifesto Revisited}

Things are happening very, very fast and we are struggling to keep up, or perhaps better said, to catch up! It 
was only a decade ago that Mackenzie Wark wrote A Hacker Manifesto (2004, online) and he was struggling then to articulate the significant, no the crucial, elements of what had already transpired in capitalist evolution. The present eludes us because we still have yet to understand the past. Yet things have now in some ways become clearer; most certainly things have moved on. But before we try to grasp the present moment let us first look again at Wark's argument.

Wark, consciously mimicking the style of the Communist Manifesto, wrote:

01. There is a double spooking the world, the double of abstraction. The fortunes of states and armies, companies and communities depend on it. All contending classes - the landlords and farmers, the workers and capitalists - revere yet fear the relentless abstraction of the world on which their fortunes yet depend. All the classes but one. The hacker class.

The "hacker class"? Terry Eagleton (2004, online) produced what could be considered the classical Marxist critique of Wark's thesis:

But it seems perverse, as well as unduly romanticizing, to hang a connection between intellectual workers and criminalized code-busters on an arbitrary metaphor. . From a Marxist viewpoint, "class" is the wrong word in any case. Intellectuals, like butchers or lap dancers, form a group rather than a social class. They don't, for example, necessarily share a single location within the means of production. Social classes are not just bunches of people with things in common. Senior citizens or people with bushy eyebrows don't constitute a potentially revolutionary class, since they are not so positioned within the capitalist system as to be capable of taking it over. You do not become a revolutionary class simply by being militant, visionary, impoverished or oppressed.

Eagleton is correct and I will come back to Wark's error in this regard in a moment. But first let us consider some of the truths that Wark (2004, online) managed to articulate.

06. As the abstraction of private property was extended to information, it produced the hacker class as a class. Hackers must sell their capacity for abstraction to a class that owns the means of production, the vectoralist class - the emergent ruling class of our time. The vectorialist class is waging an intensive struggle to dispossess hackers of their intellectual property. Patents and copyrights all end up in the hands, not of their creators, but of the vectoralist class that owns the means of realizing the value of these abstractions. The vectoralist class struggles to monopolise abstraction. Hackers find themselves dispossessed both individually, and as a class. Hackers come piecemeal to struggle against the particular forms in which abstraction is commodified and made into the private property of the vectoralist class. Hackers come to struggle collectively against the usurious charges the vectoralists extort for access to the information that hackers collectively produce, but that vectoralists collectively come to own. Hackers come as a class to recognize their class interest is best expressed through the struggle to free the production of abstraction not just from the particular fetters of this or that form of property, but to abstract the form of property itself.

The "vectoralist class"? Again we will come back to this error in a moment and rectify it. It is the same error as was made about the hacker "class". The error is not exactly small but yet it is easily remedied; and the truths Wark articulated are far more important. Wark was articulating what he had already seen, that which perhaps not many had really taken notice of as significant. But today the struggles over piracy and copyright, spying and hacktivism, have exploded into obviousness. They are ubiquitous, from the revelations of Edward Snowden, to the prosecution of Pirate Bay, to the Anonymous hacking of the Justice Department. What Wark has put his finger on is the crucial importance of electronic abstraction - economically, politically and culturally - in this extended moment of capitalist development. Copyright and piracy are not minor struggles or debates appearing at the periphery of the system of commodification - of everything - that is contemporary capitalism. They are central to it. The "surveillance society" is the internet surveillance society. The knowledge economy is crucially a computer mediated economy.

Our informational commons recently emerged as one of the key domains of the class struggle in two of its aspects, economical in the narrow sense and socio-political. On the one hand, new digital media confront us with the impasse of "intellectual property". The World Wide Web seems to be in its nature Communist, tending towards free flow of data - CDs and DVDs are gradually disappearing, millions are simply downloading music and videos, mostly for free. This is why the business establishment is engaged in a desperate struggle to impose the form of private property on this flow. On the other hand, digital media (especially with the almost universal access to the web and cell phones) opened up new ways for the millions of ordinary people to establish a network and coordinate their collective activities, while also offering state agencies and private companies unheard-of possibilities of tracking down our public and private acts (Žižek, 2014, online).

Wark's greatly extended definition of the label "hacker" is useful in trying to understand this contemporary electronic development of abstraction in the commodity form. The term "vectoralist" is useful too. For Wark the 
hacker need not be seen only as someone producing code to break and enter to either subvert the system or rob your bank account. No, Wark's understanding includes virtually all knowledge workers. As he stated more recently in an interview (Gregg, 2013, online):

To me, a hacker is someone who turns information — of any kind — into intellectual property. Hence, programmers can be hackers, but so too can scientists, artists, writers, designers, and so on. It's about how these disparate kinds of concrete activity end up in the same abstract form — as "intellectual property".

The contemporary agri-business farmer that produces the hidden corn-oil processed ingredients in the snack the financial services office worker is eating, is neither vectoralist nor hacker, though he may use many products produced by hackers and owned by vectoralists. Nor is the logger or the pulp and paper factory worker that have together provided the labour for the product upon which a portion of that office worker's labour is printed. But the office worker is a hacker, whether the office is connected to retail distribution or sales, media production or actuarial science. As Wark might say, it is all code.

Referring to hackers and vectoralists as classes was perhaps rhetorically useful also. It dramatizes their significance in the present world system. Perhaps as Eagleton says it is "unduly romanticizing" but it certainly facilitated the parody of Marx (though I am sure Wark would not think "parody" the best choice of word here). Wark's argument, I believe, is actually quite seriously Marxist ("cryto-Marxist" is how Wark describes it himself) in the best sense of that descriptor. Thus, we may forgive him his exaggerations for rhetorical effect, and as I shall argue, also for his analytical focus and clarification. It may at first glance seem strange that what I am suggesting is an error, is also useful for clarification but so be it.

We should nonetheless be clear: neither hackers nor vectoralists are classes. Eagleton was quite right in this. Rather what they are is particular segments of classes; and as Wark quite rightly makes the argument, they are particularly important... segments. It is this crucial importance that mistakenly labelling them classes enables us to clearly see.

Eagleton suggests that Hackers belong to the petite bourgeois class. In this he too is mistaken. Some hackers belong to this class and are also an important segment of it as well. And just like the petit bourgeois generally, they also frequently misunderstand their own objective interests as being those of the ruling class. Petty bourgeois hackers own their own small security firms. They own and work in small media production companies or educational provision firms. The key word is small. They are not Stratfor or Sony. The laws concerning intellectual copyright or surveillance are not being made or altered on their behalf . . though the ideological justification of such may well present the case as though they were. The State does not belong to them!

Mack Zuckerberg (2012, online) has famously stated he is a hacker and supports Wark's expanded definition:

The word "hacker" has an unfairly negative connotation from being portrayed in the media as people who break into computers. In reality, hacking just means building something quickly or testing the boundaries of what can be done.

Well, the term is flexible and open to contestation of definition. But if Zuckerberg is a hacker by some definitions, and some aspects of Wark's definition in particular, he is certainly not by others. Rather he is a vectoralist, buying the intellectual labour (the hacking) of others to profit from.

No, hackers are petty bourgeois or proles. The material difference between owning your own small company and working for Microsoft or the NSA does have its ideological effects. Just as the difference between being an owner operator taxi driver or a wage paid bus driver have different material circumstances that incline the latter more easily than the former to perceive collectivist political interest. However, in both cases, taxi owners and say, an electronica disk jockey, may nonetheless grasp their own collective interests in spite of some more superficial and deceptive circumstance. That is to say, that while ideology is facilitated by circumstance and frequently succeeds in deceiving the small business owner of whatever sort, the more fundamental objective interest of the petit bourgeois class lies with the proletariat. The most important objective interests of hackers line up together whether they own their own business or not.

The consciousness of hackers and vectoralists share the state of consciousness of the ruling class, proletariat and petite bourgeoisie. That is to say, the ruling class and its vectoralist segment understand very well their objective interests, insofar at least, as the maintenance of power is concerned. They may disagree among themselves about many things; they may fight for power and control as individuals; but where their collective interests are concerned they are united. One could make an argument that perhaps they often misunderstand their interests where profit and power conflict with more fundamental aspects of the human condition, with regard to the environment for 
example. But that would be the subject of a different paper. No, what is important here, is that with regard to the maintenance of power, the bourgeoisie understand things very well and act on that understanding on a variety of levels: economically, politically, culturally and militarily. By contrast, one can say most charitably of hackers, of the other two classes generally, proletariat and petit bourgeois, that they are divided and confused.

But let's consider Wark again:

06. Hackers come as a class to recognize their class interest is best expressed through the struggle to free the production of abstraction not just from the particular fetters of this or that form of property, but to abstract the form of property itself.

This is very important if it is true. But is it?

I would say yes ... and no. Hackers as a group are varied in their beliefs, so in that case this important recognition of what is most important with respect to their shared circumstance is an understanding only shared by some. So, in that sense no, it is not true. However, this statement by Wark (ibid) is most definitely true: "Only one intellectual conflict has any real bearing on the class issue for hackers: the property question." The principal objective condition of the "property question" is this: workers produce services and products through their labour power that the employer class buy as a commodity; or in Wark's (ibid) terms “. . . information that hackers collectively produce, but that vectoralists collectively come to own." Hackers as individuals possess a variety of beliefs and opinions concerning their situation but there is only one central collective truth (as just expressed above) concerning it. Thus, there is consistency in their articulation of resentment towards the status quo of power relations.

\section{The Political Potential of Anonymous}

The time has come to put two things together. The time has come to move from Marxism to Leninism. The time has come to consider Anonymous in the light of Wark's Manifesto.

Therefore, just as hackers have a multiplicity of beliefs, so too does Anonymous. Many Anons are anarchist libertarians. Many are socialist libertarians. Many are just simply libertarians; and they foolishly believe in the identity of market freedom and freedom more generally. Many have thought so little about political economy it is impossible to give them a label; some of them even brag about this. Many Anons are quacks. A large number of Anons are "Truthers", greatly concerned with the "truths" about 9/11, Area 51 and chem trails. Quackery is abundant and multi-variable in Anonymous discourse. But there is nonetheless some consistency in their positions.

Cornell West (2013) was asked what he thought of "Truthers" and the 9-11 conspiracy theory. He famously replied that while he did not really know what to think of the particular case, the distrust of government and its intelligence agencies was something he shared. Anonymous completely distrusts corporations, governments and the media. All Anons have that in common.

Thus far Anonymous has had little contact with "traditional" left-wing activists (apart from the occasional unpleasant brush up on the street against Black Block anarchists). However, Anonymous now has new recruits from the ranks of the "politicals". People are getting involved with them not because of any interest in hacking per se but rather because they see in Anonymous a potential to act upon the world. They see in Anonymous a new kind of organizational/non-organizational form, which, suggests new horizontal promise as an alternative to the traditional hierarchical organizational forms of both mainstream electoral politics and trade unionism on the one hand, and the far left Marxist and even anarchist organizations on the other.

This line of thinking resonates with the hopes for the Occupy movement. But while I would not wish to pronounce Occupy dead (it is far from it!) or a failure, the original hoped for potential has run its course. There were, and are, limitations to the possibilities of this sort of movement. Jose Lopez (2014) expresses the limitations succinctly:

One of the fundamental limitations of much of the leaderless, anarchic, horizontal, chaotic modes of contemporary protest/ action is the extent to which it exemplifies a type of politics (participatory, democratic, radically egalitarian) that can only be produced as an exception. Contrast the Occupies to factory occupations. The former are limited and temporary as they do not themselves produce the material conditions of their reproduction. Their function is really to educate through spectacle, to prefigure, as anarchists like to say.

Anonymous is in many ways similar to Occupy. Between Anonymous and Occupy there has been considerable 
affinity, and, I am sure, overlap in participation. And spectacle certainly features highly in the Anonymous lexicon of action types. But I would not make the claims for Occupy I wish to make for Anonymous. Yes, the Internet makes all the difference. And here we come back to Wark's argument about hackers. The internet has made possible a form of political organization/non-organization and activism hitherto unprecedented in human history.

There is no unity among Anons except for that noted above of their complete distrust of the status quo. They do not trust the government (any government because Anonymous is now international in terms of both "membership" and perspective). They do not trust corporations or the media. Thus, their opposition to the powers that be is fundamental, and I would argue, grounded precisely in what we have been considering above in terms of Wark's argument about hackers. It is precisely the property relations of this class-segment that grounds and unifies Anonymous praxis. Anonymous is, for example, highly prolific in video production. But these videos are not owned. They are constantly being remixed, cut and pasted and re-posted on the net. They resent all attempts to control this, whether on the part of You'Tube, Google, Facebook or Twitter. They use these social media daily but they don't like them. They respond aggressively to attempts to control their free flow and exchange of words, images or data ... one could say that they are naturally communist in their practices, in the sense Žižek spoke of earlier.

Most Anons would not recognize themselves in the argument I am providing here. Their praxis is an extremely under-theorized praxis; I would say unusually so. Anonymous does not come together in theory; but it does come together in practice. Their direct democracy works very simply and efficiently. Someone proposes an operation. Individuals argue about the suggestion or ignore it; they decide to support it or not. If there is not enough support the action dies on the drawing board, as it were. If enough individuals are interested and supportive, a collectivity emerges; plans are made and action is taken.

Anonymous engages with a lot of diverse issues, from paedophilia to economic inequality. However, their most consistent orientation to action, their most prevalent operations, concern the property relations of the internet. Some of them may express their understanding of this in terms of libertarian notions of freedom and free speech but the actions are actually grounded in the realities expressed in the Marxist analysis of property and exploitation, in Wark's analysis of the commodification of hacking, scarcity, abundance and abstraction.

Anonymous is not at all like Lenin in terms of articulating the consciousness of the class. Nor is their form of political organization remotely Leninist. Rather it is the very antithesis of democratic centralism. But that antithesis is precisely what is politically called for in the contemporary capitalist moment in terms of resistance.

There is a sad irony in the present moment. Marxist theory is not frozen back in the zenith of Marx's own analysis. It has substantially progressed in terms of depth and breadth of analysis; it has very nearly kept pace with the speed of change of capitalist political economy itself. Yes, very nearly, but only very nearly, because something is very wrong in the collective understanding of Marxists, anarchists and all the others who make up the Western world's Left intelligentsia. There must be something wrong there that goes well beyond this irony: the Left has never been weaker! The limits and weaknesses of electoral social democracy and traditional trade unionism have never been clearer. But the far left Marxist and anarchist parties appear to be only facing inward, tearing themselves apart with rifts and factional struggles; the significance of their action is mainly marked by its inconsequentiality.

At this moment all significant political resistance is reactive . . reactive because we do not have the initiative at this historical moment. To recognize this is not itself reactionary, but simply deciding to work from where we are. Anonymous is the de facto political leader of the hacker class-segment. It is they who are the hope for the moment. It is they, who through their actions more than words, have grasped this truth expressed by Wark (ibid.):

Hackers come as a class to recognize their class interest is best expressed through the struggle to free the production of abstraction not just from the particular fetters of this or that form of property, but to abstract the form of property itself.

It is only fitting to conclude this article with a quote from Anonymous (Aljazeera, online 2011):

\begin{abstract}
The tendency to relate past events to what is possible in the present becomes more difficult as the scope of the geopolitical environment changes. It is a useful thing, then, to ask every once in a while if the environment has recently undergone any particular severe changes, thereby expanding our options for the future. Terminology, let alone our means of exchanging information, has changed to such a degree that many essential discussions in today's "communications age" would be entirely incomprehensible to many two decades ago. As the social, political and technological environment has developed, some have already begun to explore new options, seizing new chances for digital activism - and more will soon join in. It is time for the rest of the world to understand why.
\end{abstract}




\section{References}

Anonymous. 2011. "Anonymous and the global correction” Aljazeera, February 16 http://m.aljazeera.com/ SE/201121321487750509

Eagleton, Terry. 2004. "Office Politics," The Nation (Oct. 25). < http://web1.thenation.fayze2.com/article/office-politics>

Gregg, Mellissa. 2013. "Courting Vectoralists: An Interview with McKenzie Wark on the 10 Year Anniversary of "A Hacker Manifesto", Los Angeles Review of Books (December 17). <https://lareviewofbooks.org/ interview/courting-vectoralists-interview-mckenzie-t wark-10-year-anniversary-hacker-manifesto>

Lopez, Jose. 2014. private email to the author.

Wark, McKenzie. 2004. A Hacker Manifesto. Harvard: Harvard University Press. <http://subsol.c3.hu/subsol_2/contributors $0 /$ warktext.html>
West, Cornell. 2013. Quoted by David Ferguson in "Cornel West 'still uncertain' about 9/11 'Truther' movement" The Raw Story, September 13. <http//:www.rawstory.com/ rs/2013/09/13cornel-west-still-uncertain-about-911- truther-movement/>

Žižek, Slavoj. 2014. "What is an authentic political event?," New Statesman (February 12) <http://www.newstatesman.com/ culture/2014/02/slavoj-zizek-what- authentic-political-event>

Zuckerberg, Mark (2012) “Letter to Investors," reproduced in Wired by Epicenter Staff (February 1). <http://www.wired. com/business/2012/02/zuck-letter/> 